GLOBAL JOURNAL OF EDUCATIONAL RESEARCH VOL 12, 2013: 9-17

\title{
USE OF ELECTRONIC RESOURCES BY GRADUATE STUDENTS OF THE DEPARTMENT OF EDUCATIONAL TECHNOLOGY AND LIBRARY SCIENCE, UNIVERSITY OF UYO
}

HENRY ITOHOWO OKON AND OLU OLAT LAWAL

(Received 6, September 2012; Revision Accepted 11, November 2012)

\begin{abstract}
The study surveyed the use of electronic resources by graduate students of the department of educational technology and library science in the University of Uyo. Based on a detailed literature review, a total of three (3) research hypotheses were formulated and tested on a sample size of 36 representing the total population of graduate M.Sc and $\mathrm{PhD}$ students of the department of educational technology and library science in the University of Uyo. The instrument employed for the collection of data was the questionnaire. t-Test analysis and Analysis of Variance (ANOVA) were used in analyzing the data collected. From the data analysis the following findings were advanced. That majority of the

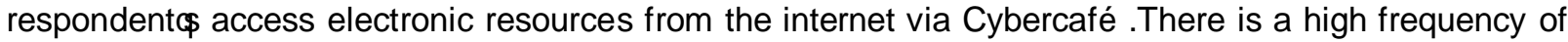
usage of electronic resources by both male and female postgraduate students of the department of educational technology and library science in the University of Uyo.
\end{abstract}

KEY WORDS: Use, Electronic Resources, Graduate Students, Cybercafé.

\section{INTRODUCTION}

While progress has been made in the past few years, much remains to be done to secure the future of the libraries and maximise their potentials for providing electronic research sources to support their Universities. The growth of research in all fields of human endeavour is becoming increasingly detailed and sophisticated, faculty members and graduate students are aware that the library has great roles to play in the provision of electronic information necessary for their day to day research. Moreover, the library acts as a medium of getting the latest scientific and technological information either in print or electronic form.
University libraries collect a variety of materials for preservation and use of the library patrons. These resources include not only traditional printon-paper media like books, journals, newspapers, and maps, but also audiovisual materials like records, audiocassettes, video cassettes and projectors.

Informed library users know that libraries have resources that are more comprehensive and scholarly than most web sites provide. Libraries provide access to scholarly literature that, as a rule, is not freely available on the Web. Often, it is in the University that students become aware of libraries resources, usually while having to write research papers. Assuming that on

Henry Itohowo Okon, Department of Educational, Technology and Library/Information Science, Faculty of Education, University of Uyo, Uyo

Olu Olat Lawal, Department of Educational, Technology and Library/Information Science, Faculty of Education, University of Uyo, Uyo 
average, most students face the same number and type of papers and assignments during their college career, it is critical to understand what makes one student use the library's electronic resources while another will not think of the library as a place to find specialized resources for their assignments. Therefore, not only do students have to find the relevant citations, but they also have to know how to locate the article after that. This means juggling many screens, many technologies, multitasking electronic jobs, and of course, knowing where to look for all this necessary information is important. There is the additional confusion that more and more library databases use Web-based technologies. Because the interface is seamless there does not seem to be a visible, on the screen, difference between Web-based library resources and general Web-based resources. All of the above also assumes the student is proficient.

\section{Statement of the Problem}

It has been proven that the quality of the University library resources depends to a large extent on the quality of its collections. The academic health, intellectual vitality and effectiveness of any university depend largely upon the state of health and excellence of its library, which most researchers have considered as its lifeblood. The thriving growth of electronic publications is reshaping the nature of collections and the mode of delivering and accessing information in libraries is changing. The traditional print resources nowadays face challenges from their electronic counterparts in faster and timely delivery of information as well as in improved access (Bandyopadhyay and Chu, 1999). This explains why the uses made of these libraries that serve higher education are many and diverse, hence, the general claim that graduate students can receive quality education if the University library has adequate electronic resources, even if they have poor or no teachers at all.

There has been a reduction in reading habits of students generally. Graduate students who are supposed to be acquiring broad based knowledge through the use electronic resources to enable them engage in a collaborative learning process towards enhancing their studies at higher levels seem not to be involved in use of electronic resources. Various reasons have been advanced for this seemingly low patronage of electronic resources by graduate students with regards to their use of University library resources. While some are of the opinion that libraries do not provide the necessary electronic resources accessibility for use like the internet, cyber café and University café, others are of the notion that graduate students use of the library is influenced by their gender and internet access competence provided for in their various University libraries. This contradiction therefore gives rise to this study which attempts to examine how graduate student use electronic resources?

\section{Research Hypotheses}

1. There is no significant means of accessibility of electronic resources by the graduate students of the department of educational technology and library science in the University of Uyo based on the media (internet, cyber café, Phone and University cafe)

2. There is no significant difference in the level of use of electronic resources between male and female postgraduate students of the department of educational technology and library science in the University of Uyo.

3. There is no significant difference in the of utilization of electronic resources based on the internet access competence

\section{Background of the study}

University of Uyo was established October 1, 1991 by the Federal Government of Nigeria. The University of Uyo inherited students, staff, academic programmes and the entire facilities of the erstwhile University of Cross River State established by Cross River State in 1983. Furtune (2010) observed that The University of Uyo is classified by the National Universities Commission (NUC), for funding purposes, as one of the second generation Universities in Nigeria even though it was founded as a Federal University in 1991. On inception, it inherited the two campuses of the former University of Cross River State, which it replaced. The latter was founded in 1983 as a state University. It occupies a town campus, annexe campus and a main campus which is a few kilometres away from both the town and annexe campuses. The university is committed to the development of highest academic standards both at the undergraduate and graduate levels. The university currently has twelve faculties with the department of 
educational technology and library science directly under the faculty of education. The university is committed to the development of highest academic standards both at the undergraduate and postgraduate levels. The University library has an active collection of 46,745 volumes and handles about 409,977 lending and reference enquiries annually. Current journals stand at slightly higher than 271 representing all disciplinary interests. The library is equipped with modern computers and has a reading space of 970.51 metres with seating capacity for 698 . Currently, there are four main divisions which include acquisition, lending, processing and research. The Research Division comprises reference, serials, special collections and government collections. The Special Collection is comprised of Nyong Essien, Africana and government collections. Acquisition and processing selects and orders library materials and organises them for effective use. The Public Service Division deals directly with readers and regulates the use of library materials. It also handles reference questions. The office of university librarian provides data for planning, budgeting, control and co-ordination of the entire library.

\section{Scope of the Study}

The study focuses on the use of electronic resources by graduate students of the department of educational technology and library science, University of Uyo, Akwa lbom State. From the Universities, polytechnics, and other higher institutions found in the state only University of Uyo, Akwa Ibom State, has a library school. Consequently, this study was carried out within the department of educational technology and library science, University of Uyo and the respondents of interest to the study were graduate MSc/MLs and PhD students of the department.

\section{Review of related literature}

Previous studies on graduate student $\hat{\Phi}$ use of electronic resources are numerous, but only a few of them will be reviewed as seen below. Writing on the importance electronic resources by students, Igabaria, Guimares \& Davis, (1995) observed that there are several ways in which web experience can be defined and conceptualized. In general, web experience can be considered to be an act where users engage in applications that are often centered on web. In addition, web experience also can be defined in two different ways as perceived use and variety of use. "While perceived usage refers to the amount of time spent interacting with the web and the frequency of use, variety of use refers to the importance of use and the collection of web package/program use. Dutton (1990), Brophy (1993) and Blandy \& Libutti, (1995) believe that in order to utilize the growing range of electronic resources, students must acquire and practice the skills necessary to exploit them. "For students using a variety of on-line databases, it is as though they were parking lot attendants, where every vehicle is not only a different make and model but has a different configuration.

The ability to find and retrieve information effectively is a transferable skill useful for future life as well as enabling the positive and successful use of the electronic resources whilst at a University. Brophy argues that libraries must "reach a position where the acquisition of information skills is acknowledged as one of the key learning objectives for every student entering a University, so that no student leaves without being fully equipped to cope with the information intensive world - the information society - as an end-user" (Brophy, 1993)

The gender dynamics relating attitudes about the Internet and actual utilization of the medium have not been adequately studied to date (Busselle, R., J. Reagan, B. Pinkleton, and K. Jackson, 1999). Nevertheless, research regarding computer use more generally has highlighted the significance of interest and stereotyping about computers, as well as selfperception of ability in explaining gendered patterns of behaviour vis-à-vis this technology (Campbell, 1990; Levin and Gordon, 1989; Reinen and Plomp, 1997; Shashaani, 1993). Investigations with elementary and high school students as well as adults reveal a significant gulf between male and female interest in computers (Campbell, 1990; Levin and Gordon, 1989; Reinen and Plomp, 1997; Shashaani, 1993). For example, drawing on representative national samples of elementary, lower, and upper secondary school students from 20 countries in 1989 and 10 countries in 1992, Reinen and Plomp, (1997) find that females enjoy using the computer less than do male students. In addition, research has found that men and boys have significantly more positive attitudes toward computers and more stereotyped attitudes regarding who is capable of using them (Levin 
and Gordon, 1989; Whitley, 1997), while female students' attitudes and attributions toward computers discourage them from using the technology (Campbell, 1990). The inference drawn is that gendered attitudes are central to discrepancies in use. Beyond attitudes, the literature points to another important factor that influences technology use: Internet access competence, which the literature has revealed that internet, has become the most extensively used information source that empowers the average person to get in roaming with the latest information. The internet has emerged as a powerful educational tool. With the increasing impact of information and communicative technologies on higher education, all those concerned with teacher education are attempting to grasp how ICT could help in modernising the process of teaching, learning and research. This implies that in this era, teachers and students can carry forward their work on the internet in ways that are similar to and tightly intertwined that in this era,on the internet in ways that are similar to and tightly intertwined with the traditional ways that they learn, teach and study in libraries, classrooms, laboratories, seminars, and conferences. Thus, the internet can provide access to essentially unlimited resources of information not conventionally obtainable through other means. Bandura (1977) beliefs revolve around cone's capability to organize and execute the courses of action required to manage prospective situations" and includes both anxiety and enactive and vicarious experience regarding task-specific competencies.

Recent literature on technology presents a complicated picture of the relationship between gender and Web use. While most scholars agree that the gender gap in internet use has narrowed significantly in the college age group (Goodson, McCormick, \& Evans, 2001; Odell, Korgen, Schumacher, \& Delucchi, 2000) as well as the general population (Brenner, 1997; Jackson, Ervin, Gardner, \& Schmitt, 2001; Newburger, 1999; Ono \& Zovodny, 2003), some gender differences have been found in attitudes toward technology, intensity of Internet use, online applications preferred, and experience in cyberspace. Investigations of college student Web use have proven especially insightful, as research on this group allows for an examination of gender differences within an institution in which men and women generally have equal access to the Internet (Odell et al., 2000). The scholarship on gender and Web use sometimes seems contradictory, demonstrating the dynamic nature of the interaction, as well as the need for continued investigation. In a study of college students' attitudes toward technology, Smith and Necessary (1996) found that males had significantly more positive attitudes toward computers than females did. Jackson et al. (2001) also found that females in general reported less favourable computer attitudes. Other literature, however, contradict these findings. Similar findings have revealed that gender had no significant effect on any of the dimensions of computer attitude studied (Jennings \& Onwuegbuzie, 2001; Shaw \& Gant, 2002). Furthermore, Zhang, (2002), Bimber (2000) both argue that the gender gap in the Internet is larger where more intensive Web use is concerned. Ono and Zovodny (2003) also found women to be less frequent and less intense users of the Internet. Concern about gender inequality has now shifted from access to intensity.

The most pronounced gender difference in Web use is found in the online applications used by males and female. Male college students are more likely than their female counterparts to use the Internet for recreational purposes, while females are more likely to use the internet to talk to family and friends (Goodson, McCormick, \& Evans, 2001; Jackson et al., 2001). These findings appear to reinforce the widespread assumption that men prefer to use the Web for information gathering and entertainment and women prefer to use the Internet for communication (Shaw \& Gant, 2002).

\section{Methodology}

The survey method was used, with a questionnaire designed to obtain the opinions of students at the department of educational technology, University of Uyo, Akwa Ibom State, Nigeria. During the last two weeks of January 2011, the researcher along with penultimate undergraduate students in the department of educational technology and library science distributed 36 questionnaires in all, for about two hours daily to the graduate students who were mostly resident off campus. Attempts were made in asking each graduate to fill a questionnaire and return it to the office assistant on duty at the departmental general office. The time of distribution varied in order to obtain a wide distribution of graduate students. During this two 
weeks period, 36 students returned their questionnaire to the office assistant. Thus, the return rate was $100 \%$ in all.

The data collected reflected the population of graduate students who use the University of Uyo libraries. The concerns of undergraduate students were not considered, in January 2011 there were 42 registered library users drawn from among Masters and PhD students of the department of educational technology and library science, University of Uyo. The breakdown of the student population is as illustrated in table 1 below.

Population is as illustrated in table 1 below.

Table 1: Population Breakdown for the Study

\begin{tabular}{|l|l|l|}
\hline Level of Study & Population & Percentage Population \\
\hline PhD & 14 & $39 \%$ \\
\hline M.Sc & 22 & $61 \%$ \\
\hline Total & $\mathbf{3 6}$ & $\mathbf{1 0 0 \%}$ \\
\hline
\end{tabular}

(Source: Department of Educational Technology and Library Science Admission Register for 2011).

The questionnaire first considered each graduate students general background information on items $1-5$, before questions that enquired about their use patterns. Items 6 of the questionnaire enquired from the students their accessibility of electronic resources through internet, cyber café and University café. Items 7 enquired about their level of use of electronic resources between male and female while items 8 enquired of their internet access competence. The questionnaire structure was adopted with few modifications from Okonês (2011) questionnaire which was found to be valid and reliable for the collection of data for this study. The data collected was subjected to t-Test and Analysis of Variance (ANOVA) which were displayed in tables.

\section{Findings and Discussion}

A total of 36 questionnaires were distributed to respondents and were successfully retrieved giving a $100 \%$ return of rate. The analyses of the distribution were as presented below.

Table 2: Level of accessibility of Respondents

\begin{tabular}{|l|l|l|l|l|}
\hline Variable & $\mathrm{N}$ & $\mathrm{X}$ & $\mathrm{SD}$ & $\mathrm{t}$ \\
\hline & & & & \\
\hline Accessibility & 36 & 16.58 & 2.12972 & $46.720^{*}$ \\
\hline & & & & \\
\hline
\end{tabular}

${ }^{*}$ significant at 0.05 level; $\mathrm{df}=\mathbf{3 5}$; critical $\mathrm{t}$-value $=\mathbf{2 . 0 3 0}$

The null hypothesis states that there is no significant accessibility of electronic resources by the graduate students of the department of educational technology and library science in the University of Uyo. In order to test this hypothesis, t-test analysis was used to analyze the data which showed sample t-Test analysis of the accessibility

of electronic resources by the graduate students of the department of educational technology and library science in the University of Uyo. The 
above table presents the t-Test value as (46.720). This value was tested for significance by comparing it with the critical t-value $(2.030)$ at 0.05 level by means of the 35 degree of freedom. The obtained t-value (46.720) was greater than the critical t-value (2.030). Hence, the result was significant. This therefore means that there is significant accessibility of electronic resources by the graduate students of the department of educational technology and library science in the University of Uyo. The above indicates that majority of the respondent access electronic resources from the cybercafés. This corroborates Obuh, (2007) report which stated that cybercafés are the most readily available access to the electronic resources by users.

Table 3: Use between male and female of the Respondents

\begin{tabular}{|l|l|l|l|l|}
\hline Variable & $\mathrm{N}$ & $\mathrm{X}$ & $\mathrm{SD}$ & $\mathrm{t}$ \\
\hline Male & 18 & 18.1667 & 1.09813 & \\
\hline & & & & $6.693^{\star}$ \\
\hline Female & 18 & 15.0600 & 1.68034 & \\
\hline
\end{tabular}

* Significant at 0.05 level; $\mathrm{df}=34$; critical $\mathrm{t}$-value $=\mathbf{2 . 0 4 2}$.

The null hypothesis states that there is no significant difference in the level of utilization of electronic resources between male and female postgraduate students of the Department of Educational Technology and Library Science in the University of Uyo. In order to test this hypothesis, Independent t-test analysis was then used in comparing the mean score of the two independent groups (male and female); see table 2 above. The above table presents the t-test value (6.693). This value was tested for significance by comparing it with the critical tvalue (2.042) at 0.05 level with the 34 degree of freedom. The obtained t-value (6.693) was significant. The result therefore means that, there is significant difference in the level of utilization of electronic resources between male and female post graduate students of the department of educational technology and library science in the University of Uyo. From the figure above a majority of $19(53 \%)$ with a standard difference of 1.68034 respondents were females. This is in agreement with Adomi (2000) who reported that there are more females than males in Library Schools in Nigeria. This invariably means that female postgraduate students utilize more electronic resources than the male postgraduate students.

Table 4. One-way Analysis of variance of the difference in the level of utilization of electronic resources based on the media (internet, cyber café, phone internet and University cafe) used.

\begin{tabular}{|l|l|l|l|}
\hline $\begin{array}{l}\text { Electronic } \\
\text { Resources }\end{array}$ & $\mathbf{N}$ & $\mathbf{X}$ & SD \\
\hline 1.00 & 6 & 13.5000 & 0.54772 \\
\hline 2.00 & 8 & 14.8750 & 0.83452 \\
\hline 3.00 & 10 & 17.3000 & 0.67495 \\
\hline 4.00 & 12 & 18.6667 & 0.98473 \\
\hline Total & 36 & 16.5833 & 2.12972 \\
\hline
\end{tabular}




\begin{tabular}{|l|l|l|l|l|}
\hline & Sum of square & Df & Mean square & f \\
\hline Between Group & 137.608 & 3 & 45.869 & \\
\hline & & & & $69.428^{*}$ \\
\hline Within Group & 21.142 & 32 & 0.661 & \\
\hline Total & 158.750 & 35 & & \\
\hline
\end{tabular}

*Significant at 0.05 level; $\mathrm{df}=\mathbf{2} \& 33$; critical $=3.29$.

The above table 3 shows the calculated f-value as (69.428). This value was tested for significance by comparing it with the critical $f$ value (3.29) at 0.05 level with 2 and 33 degree of freedom. The calculated f-value (69.428) was greater than the table f-value (3.29). Hence, the result was significant. The result therefore means that there is significant difference in the level of utilization of electronic resources based on the media (internet, cyber café, phone internet and University cafe) used. From table 3 , it was observed that there is a difference in the level of electronic resource experience amongst respondents too. This corroborates with what was reported by Dutton (1990) and Brophy (1993) that students do not often appreciate the skills required to search electronic sources, stating that they are deceptively easy to use.

\section{Summary of the Study}

In this study, the Use of Electronic Resources by Postgraduate Students of the Department of Educational Technology and Library Science in the University of Uyo was examined. Based on literature review, research hypotheses were formulated and tested on a sample size of 36 representing the total population of postgraduate MSc and $\mathrm{PhD}$ students of the department of educational technology and library science in the University of Uyo. The instrument employed for the collection of data was the questionnaire. t-Test analysis and analysis of variance (ANOVA) were used in analyzing the data collected. From the data analysis the following findings were advanced.

That majority of the respondent $\hat{\mathbf{s}}$ access electronic resources from the internet via Cybercafé .There is a high frequency of usage of electronic resources by both male and female Postgraduate Students of the Department of Educational technology and library science in the University of Uyo. In other words gender gap in electronic resource usage is quite negligible. Issues like large mass of irrelevant information, the need to filter the results from search, download delay, failure to find information, inadequate/lack of search skills, high cost of access, power outages, inaccessibility of some electronic resources, difficulties in navigating through electronic resources and so on are problems encountered when using electronic resources by graduate students the department of educational technology and library science in the University of Uyo..

\section{CONCLUSION}

It has been determined in this paper that graduate students of the department of educational technology and library science in the University of Uyo need high level of usage of electronic resources even as evident among both male and female gender which is an indication to the fact that even without the expertise knowledge of manipulating information in an electronic environment, students are still getting satisfaction from the little they could get out of electronic sources although handicapped by their low level of accessibility. This high level of use is also as a result of their perception of ease and usefulness of electronic sources such as the web.

\section{Recommendations}

Based on the findings of the study the following recommendations were made by the researcher;

- Government should equip schools with the enabling infrastructure such as adequate power supply, effective internet connectivity etc. that will encourage the usage of ICTs by students.

- ICT centres with well trained personnel should be established in the universities where students can have free access to computers, the web and other electronic sources. 


\section{REFERENCES}

Adomi, E. E., 2006. Mobile phone usage patterns of library and information science students at Delta State University, Abraka, Nigeria. Electronic Journal of Academic and Special Librarianship.

Bandura, A., 1997. Self-efficacy: The exercise of control. New York, NY: W.H. Freeman.

Bandyopadhyay, A., and Chu, H., 1999. Electronic journals versus print journals: An evaluation framework. Proceedings of the Twentieth National Online Meeting . ( New York Hilton).

Bimber, B., 2000. Measuring the gender gap on the Internet. Social Science Quarterly 81 (3): 868-876.

Blandy, S. G., Libutti, P., 1995. As the cursor blinks: Electronic scholarship and undergraduates in the library. Library Trends 44 (2): 279-305.

Brenner, V., 1997. Psychology of computer use: XLVII. Parameters of Internet use, abuse and addiction: The first 90 days of the Internet Usage Survey. Psychological Reports 80 (3): 879-882

Brophy, P., 1993. Networking in British academic libraries. British Journal of Academic Librarianship 8 (1): 49-60.

Brosnan, M. J., 1998. The impact of computer anxiety and self-efficacy upon performance. Journal of Computer Assisted Learning 14 (3): 223-235.

Brown, P., Challagalla, G., and Ganesan, S., 2001. Self-efficacy as a moderator of information seeking effectiveness. Journal of Applied Psychology 86 (5): 1043-1051.

Busselle, R., J. Reagan, B. Pinkleton, and Jackson, K., 1999. Factors affecting Internet use in a saturated-access population. Telematics and Informatics 16 : 45ï 58.
Campbell, N., 1990. High school students' computer attitudes and attributions: Gender and ethnic differences. Journal of Adolescent Research 5: 485 ï 99.

Dalgleish, A., and Hall, R., 2000. Use and perceptions of the World Wide Web in an information seeking environment. Journal of Library and Information Science 32 (3): 104-16.

Dutton, B. G., 1990. An introduction to end-user searching. In: Bysouth, P. T. (ed) Enduser searching: the effective gateway to published information. London: Aslib,118.

Goodson, P., McCormick, D., and Evans, A., 2001. Searching for sexually explicit materials on the Internet: An exploratory study of college students. Archives of Sexual Behaviour 30 (2): 101-118.

Igabaria, M. T., Guimares, T., and Davis, G. B., 1995. Testing the determinates of microcomputer usage via a structural equation model. Journal of Management Information Systems $4: 87 i ̈ 114$

Jennings , S. E., and Onwuegbuzie, A. J., 2001. Computer attitudes as a function of age, gender, math attitude, and developmental status. Journal of Educational Computing Research 25 (4): 367-384

Kibirge, H. M. and DePalo, L., 2000. The Internet as a source of academic research information: findings of two pilot studies. Information Technology and Libraries 19: 11-16.

Levin, T., and Gordon, C., 1989. Effect of gender and computer experience on attitudes toward computers. Journal of Educational Computing Research 5 :69 ï 88.

Newburger, E. C., 1999. Computer use in the United States. October 1997. Current Population Reports, U. S. Census Bureau (pp. 1-11). Available: http://www.census.gov 
Obuh, A. O., 2007. Accessibility and used of the Internet by undergraduate students of Nigeria University. Educational Trends $13: 108-123$.

Odell, P. M., Korgen, K. O., Schumacher, P., and Delucchi, M., 2000. Internet use among female and male college students. Cyberpsychology and Behaviour 3 (5): 855-862

Okon, H. I., 2011. Influence of postgraduate students and library variables on utilization of library resources in the south-south zone universities of Nigeria.

Unpublished Doctor of Philosophy (Ph.D) thesis submitted to the department of educational technology and library science, faculty of education, University of Uyo.

Ono, H., and Zavodny, M., 2003. Gender and the Internet. Social Science Quarterly 84 (1): 111- 121.
Smith, B. N., and Necessary, J. R., 1996. Assessing the computer literacy of undergraduate college students. Education 117 (2): 188-193.

Shashaani, L., 1993. Gender-based differences in attitudes toward computers. Computers \& Education 20:169ï 81.

Shaw, L. H., and Gant, L. M., 2002. Users divided? Exploring the gender gap in Internet use. Cyberpsychology \& Behaviour 5 (6): 517-527

Whitley, B., 1997. Gender differences in computer-related attitudes and behaviour: A meta-analysis. Computers in Human Behaviour 13:1ї 22.

Wilson, T., 2000. Web's gender shift more than a curiosity. Internet Week $827: 28$.

Zhang, Y. X., 2002. Comparison of Internet attitudes between industrial employees and college students. Cyberpsychology \& Behaviour 5 (2): 143-149. 